\title{
Was Federation motivated by federalism?
}

\author{
Greg Melleuish ${ }^{1}$
}

\section{Abstract}

Australia is a federation that does not really believe in federalism. Whenever matters pertaining to the workings of federalism appear, comments made in the press or online advocate the abolition of the states and the creation of a central national government. It is assumed that state governments are venal, incompetent and inherently inferior to the Commonwealth Government. How do we explain this peculiar phenomenon?

\section{Introduction}

Australia has a very peculiar political system in that it is a federation that does not really believe in federalism. Certainly, there are advocates of states' rights, more than often found in Western Australia, but it is rare to find anyone who believes in the virtues of federalism as an institutional means of governing the country. Whenever matters pertaining to the workings of federalism appear in the press or online, comments made under such articles advocate the abolition of the states and the creation of a central national government. It is assumed that state governments are venal, incompetent and inherently inferior to the Commonwealth Government.

How do we explain this peculiar phenomenon?

1 The University of Wollongong, gmelleuish@gmail.com. 
Federalism is an unusual form of political order sitting between the small, self-governing community and the large, territorial state or empire. It seeks to reconcile these two forms of political entity, thereby, at least in theory, bringing together the advantages of local self-government and the economic, political and military capacity that only a large political entity can possess. Federalism has its ancestry in places such as ancient Greece and medieval Germany, where small political entities came together in leagues so as to pursue common interests while at the same time keeping control of their own affairs. Over time, these leagues tended to be absorbed into empires and larger territorial units, such as happened with the Roman Empire in the case of ancient Greece, and in modern Germany.

Federalism is similar to the idea of mixed government in that both advocate a form of government in which power is shared rather than being concentrated in a single source. In this regard, a federal system sits uneasily with an idea of a single sovereign entity sitting at the apex of the political system. In fact, the problem with the idea of sovereignty is that it seeks a precise or scientific notion to the problem of the organisation of political power, when, of course, the situation in the real world is always much more complex and power is diffused. This was the case in medieval Europe, where there were multiple sources of authority. It is only really with Bodin, who disliked mixed government, that the idea emerged that there was only a single source of authority in a polity (de Benoist, 2018, pp. 104-106).

This scientific desire culminated in Thomas Hobbes' Leviathan, where, in a sense, politics is solved by geometry, by bringing together a collection of amorphous individuals into single collective that requires a single source of authority (Hobbes, 1991). In a similar fashion, the French Declaration of the Rights of Man creates a similar binary model of individual and nation (or state). The key clause is

3. The sources of all sovereignty resides essentially in the nation; no body, no individual can exercise authority that does not proceed from it in plain terms. ${ }^{2}$

The opposite position can be found in Johannes Althusius' Politica, in which he argues in favour of what he terms federalism by which he means the idea that a political community is composed of a number of groups or associations (Althusius, 1995). In many ways, the role of associations may be crucial for the success or otherwise of a federal system of government. It is what Alexis de Tocqueville, an anti-Jacobin, saw as the distinctive feature of American democracy (see Jaume, 2013, pp. 21-64). It was also what J.D. Lang emphasised in his account of America (Lang, 1840).

This division of sovereignty leaves open the possibility that one of the elements sharing that sovereignty will eventually come to dominate and impose itself on the others. In the case of the mixed constitution of England, this issue was resolved by vesting sovereignty in parliament, which was 'mixed' in that it represented the

2 www.historyguide.org/intellect/declaration.html. 
monarch, the lords and the commons. In this way the unitary nature of sovereignty was reconciled with its 'mixed' elements, although it can be argued that the consequence was the creation of a unified sovereign entity.

This explains the argument of the advocate of Australian federalism, John West, writing in 1854. West argued that the many small associations of English society acted as a brake on the power of the central English government. West believed that such associations were weak in the Australian colonies and he proposed that a federal system could create the checks and balances required in such circumstances (West, 2001, p. 26). This raises the issue of the extent to which artificial constructions can be substituted for organic associations.

The idea that civil associations were weak in the Australian colonies can be contested. In their recent history of Evangelicals in Australia, Piggin and Linder point to the importance of churches as forms of civil association in the colonies, and that members of churches were central to establishing other forms of civil associations, such as mutual societies (Piggin \& Linder, 2018). In the latter part of the nineteenth century, one can also see the development of other forms of association such as trade unions (Gollan, 1960, esp. Chapters 4, 5, 6). There can be no doubt that the third quarter of the nineteenth century was the heyday of voluntary associations in Australia; along with mutual societies and friendly societies, there were also mechanics' institutions established for the purpose of self-education (Nadel, 1957, pp. 111-160).

On the other hand, the transportation of convicts meant that convicts were effectively 'dumped' into a society where they had few, perhaps no, connections, although some convicts could bring family out to the colonies, as happened when my great-great-grandmother joined my great-great-grandfather in the early 1820 s.

Nevertheless, the fact that so much of the incoming population came as individuals rather than families, as was also the case with the gold rushes, meant that associations in the colony were not organic and needed to be created out of a collection of strangers. It is extremely important that, in New South Wales and Victoria, a centralised government preceded local government (Hirst, 1988, pp. 243-265). A degree of local initiative existed but there was also a very strong incentive to look to the government of a colony to do things, as happened in the key areas of education and railways.

The colonial governments can be understood as newly minted artificial constructions trying very hard to pretend that they embodied the organic qualities of British government. In a similar way, the Federation movement, despite the rhetoric about the crimson thread of kinship, can be understood as an exercise in constructing an artificial political structure. The delegates at the various conventions were imbued 
strongly with the idea of an organically evolving British Constitution but recognised that they were bringing a constructed entity into being (Chavura \& Melleuish, 2015, pp. 512-528).

Federal political structures, understood as artificially created institutions, have a certain instability. Sir Robert Menzies famously stated that either the central government or the states will come to dominate (Menzies, 1967, p. 2). The apportionment of power between them brings a very real tension into being. There is also a distinction between a confederation and a federation, with a confederation involving much looser bonds among its members. In the case of the Australian Federation, it is clear that the bonds were meant to be relatively strong and permanent as indicated by the preamble's reference to an 'indissoluble union under the crown'.

Moreover, the English tradition of government evolved over time towards centralism; parliament was sovereign and the ultimate source of authority. The Australian colonies inherited a form of polity, 'responsible' or 'party' government that was quite different to that which the American colonies had adapted from Britain in the 1780s. The British version of 'responsible government' was essentially aristocratic; parties were a little like aristocratic clubs who shared power.

Two points are particularly relevant here:

- The norm for British settler communities by the middle of the nineteenth century was for the imperial power to encourage local self-rule within the wider imperial framework (Ward, 1976). Australia, like America and Canada, was settled both at different times and in different places, and under a variety of circumstances. South Australia was always a free colony while most of the others had convicts at some stage. The most powerful tendency in the midnineteenth century was towards separating out the colonies rather than bringing them together. The ideal of an empire of small self-governing communities was pushed in Australia by figures such as J.D. Lang as part of his vision of creating an Australia composed of yeoman republics (see Melleuish, 1999, pp. 22-23). There was great enthusiasm for the idea that the colonisation of Australia should follow the model of the ancient Greeks. Colonies would model themselves on their place of origin but be independent of them. They would run their own affairs, but still be linked to 'home' by ties of kinship and affection.

- When it came to the issue of the form of government that the colonies would adopt, the evolution of what would become the Westminster system was moving away from an eighteenth-century concern with the need to restrict the power of government and to root out corrupt practices, and towards a model of government that tended to centralise power. Responsible government, as it developed in the Australian colonies in the second half of the nineteenth century, took on strong centralist tendencies. Power was concentrated in the various governments who could then use it for purposes of economic development. Local critics such as 
William Forster bemoaned the way in which responsible government failed to provide much in the way of checks and balances to resist the power of the executive (Melleuish, 2014, pp. 90-94).

A degree of concentration of political power made sense in a political entity that had economic development as its major objective. Railways needed to be built and there was insufficient private capital to do so. Primary education required that governments build schools. Colonial governments built railways and opened schools out of financial necessity, but the results were extremely centralised systems. The nature of colonial governments matters, because that is where the men who drew up the Commonwealth Constitution learned their political trade.

If one goes back to the 1850s, there was still a strong ideal in the colonies of 'mixed government'(Melleuish, 2014, pp. 65-87). By mixed government is meant the idea that the concentration of power is something to be avoided and that power should be distributed among a variety of groups in a political community. This is why John West advocated federalism in the 1850 s as a means of recreating mixed government by splitting power between local and central governments. West was particularly concerned about the possible despotic excesses of democracy in small communities; he hoped that a federal structure would divide power and prevent either level of government from being too dominant. West was worried that small democratic communities would enact selfish legislation that would harm minorities, such as the Chinese, or seek to benefit themselves at the expense of others, such as in the case of protective tariffs. Unchecked democratic majorities simply could not be trusted to act in a just fashion (West, 2001, pp. 22-25). In the absence of traditional British social structures within colonial society, that which had not been provided by nature would need to be supplied by artifice. The model is mechanistic, but perhaps this was inescapable given the peculiar circumstances of the Australian colonies.

When the British Government granted responsible government to the Australian colonies in the 1850s, it was also concerned that the various colonies would adopt an array of policies that might place some of them at odds with other colonies. This concern was not without foundation, given the level of conflict that existed in the United States. The colonists were encouraged to adopt some sort of federal structure, although there was no model of what such a structure would look like. In a similar vein, West understood the value of federalism in terms of political theory but was hazy regarding its institutional design.

From an imperial point of view, the value of federalism lay in the expectation that it would create a measure of uniformity; diversity, especially in crucial policies, was not a desirable thing. What is interesting is the degree of conformity in the models of responsible government adopted by the various Australian colonies. They were all bicameral. They all adopted a relatively broad franchise, if not universal manhood suffrage, for the lower house, and an upper house that was designed to resist democratic excess (Melleuish, 2007, pp. 112-114). 
Federalism, from the imperial perspective, was clearly seen as desirable because it would allow for some sort of coordination among the various colonies. There was an absence of coordination when the colonies were free to do as they chose; for example, in the absence of any central authority, each colony developed its own policy on tariffs. Over time, it appeared that the legislative consistency of the various British communities would fracture. For example, my great-grandfather married his deceased wife's sister in Sydney at a time when such marriages were still illegal in Britain.

Federalism made sense on what are essentially utilitarian grounds. The British Empire grew in a remarkably unsystematic fashion and the imperial authorities came to accept that the various settler societies composed of peoples from the British Isles should run their own affairs, at least within certain limits. The imperial authorities desired a degree of uniformity but knew that it could not be imposed on its overseas colonies. Encouraging federal structures seemed like a reasonable way to proceed, in that it would encourage a degree of commonality among the political, social and economic practices of 'Greater Britain' (Belich, 2009, pp. 456-478).

Of course, having attained responsible government, the various Australian colonies showed little desire to come together. The next 40 years, it can be argued, established the foundations of the way in which politics would function in Australia. Initially, there was a strange mixture of utopianism and anxiety (Melleuish, 1994, pp. 114-133), which was compounded by teething pains as people with very little political experience attempted to run a parliamentary system.

By the 1870s, a decade of considerable prosperity, the colonists had established what would become their political traditions within the framework of working systems of responsible government. As J.M. Ward has argued in the case of New South Wales, this led to a more relaxed and conservative approach to political matters, combined with a desire for material development (Ward, 2001, pp. 1-36). As this was the political tradition and experience that was defining for those who drew up the Commonwealth Constitution, it was far more important for them than any theoretical understanding of federalism.

For earlier figures such as John Dunmore Lang, the whole point of the colonial enterprise was to establish a series of small self-governing entities that would be democratic in nature. They would be like Greek colonies in the sense that what bound them together would be ties of affinity and shared values. It should be noted that the 1850s were a highpoint of a faith in free trade and its capacity to transform the world so that universal peace and the brotherhood of man would reign.

The men who came to draw up the Commonwealth Constitution came from colonies that had entrenched a centralised form of representative government in the form of 'responsible government'. As discussed, New South Wales and Victoria 
had not developed strong systems of local government. After 1859, the desire for separation appeared to have largely abated; there would be no new colonies created. The railways, owned by the various colonial governments, invariably led back to the capital that dominated the colony. In particular, Melbourne dominated Victoria and Adelaide basically was South Australia.

The advocates of Federation were men who aspired to distinction and a status appropriate to their standing in the community. West had argued that one of the advantages of a federal sphere was that it would create a type of government and legislative body that would enable men of distinction to debate and discuss higher issues of politics founded on principle (West, 2001, p. 41). Local assemblies concerned themselves with much more material and mundane matters.

The quest for distinction in colonial Australia manifested itself in the desire of colonial politicians to acquire the word 'Sir' before their names, such as Sir 'Enry Parkes. They wanted their Britishness affirmed by being awarded the sorts of honours to which all those of British stock aspired (Hirst, 1988, pp. 105-118). Equally, those colonies that had once been home to convicts craved respectability. There were still former convicts around when Federation took place, including one of my great-great-grandfathers.

One key factor is that by the 1880 s the strategic environment in which Australia was placed had changed significantly. The British navy, which had guaranteed the universal peace of the era of the free trade world of the 1850s, was being increasingly challenged to maintain that order. As Clinton Fernandes argues, there was 'strong popular support' in the Australian colonies for the use of force by the British Empire (Fernandes, 2018, p. 19).

What can be said is that the move towards Federation in the late 1880s occurred in a very different environment from that of the late 1840s and 1850s. The optimism and utopianism of mid-century was slowly leached away as the European world moved into the darker waters of the fin de siècle. There was a growing focus within the West on decay and degeneration.

The increasingly pessimistic mood of the 1890s is caught by the Bulletin and C.H. Pearson's National Life and Character. Pearson believed that liberalism had, in a sense, exhausted itself, and was being replaced by what he termed 'state socialism' (Docker, 1990, pp. 167-171; Pearson, 1893). One can also not underestimate the influence of the ever-pessimistic David Syme in Victoria, his gloomy view of human nature and his advocacy that the state constrain and regulate human actions (Melleuish, 2014, pp. 107-123).

The mood of the 1890s, the decade in which Federation occurred, was quite different to that of the 1850s when the idea of Federation was first considered. The bush was tethered to the world after 40 years of railway building, and it was also the case that 
the railways, along with the education system, created the first large bureaucracies in the Australian colonies. George Reid both introduced a radical free trade regime in New South Wales and sought public service reform to create a more uniform bureaucracy. Colonial democracy in its green years had had a somewhat amateur air to it and politicians exercised great personal influence over government and the way in which it operated. The era of the individual liberal politician was being replaced by one in which political parties and public service bureaucrats became more important.

The men who created Federation were the products of this changing world. By the 1890 s the Australian colonies were being increasingly integrated into the British imperial order. The second half of the nineteenth century saw not only the construction of the railways but also the telegraph, the growth of steamship travel, all of which conquered the earlier 'tyranny of distance' (Kern, 2003). This 'new world order' was matched by the emergence of 'progressivists' in Australia (Roe, 1985).

The Australian colonies had developed their own distinctive versions of 'responsible government' that were driven by an impulse to centralise. They now lived in a world that was less 'relaxed and comfortable' than had been the case 40 years earlier. Older political ideas, in particular those relating to 'mixed government' that recognised the need to create a system of checks and balances to restrict concentration of power, had largely faded into history.

One element of this new political mood was the adoption of the 'pledge' and the delegate model of democracy by the fledgling Labor Party, a move designed to discipline its members. David Syme, it should be noted, was another great supporter of the idea that members of parliament were no more than agents of the people who had elected them and should act under instructions (Melleuish, 2014, p. 118). Of course, the men who drew up the Commonwealth Constitution were liberals to a man. But among them were a significant number of 'new liberals', such as the Oxford-educated Bernhard Wise, as well as the Deakinites, students of C.H. Pearson and protégés of David Syme.

There is also the man who lit the Federation fuse, Sir Henry Parkes, at the fag end of his career, in a move that was clearly motivated by a desire to establish a legacy for himself. In his famous speech of 1889, Parkes dwells on the 'crimson thread of kinship', on Australia as a nation and on the need to bring an Australian people into being. Parkes was a man who sought distinction. He was also not a political figure who understood the importance of limiting and dividing political power. In his Tenterfield speech, Parkes rejects the idea of a loose arrangement amongst the colonies: 
Some colonial statesmen had said that this might be done by means of the Federal Council; but this Federal Council had no power to do anything of the sort, as it had no executive function; and, moreover, was not an elective body, but merely a body appointed by the Governments of the various colonies; and, did not, therefore, carry with it the support of the people. (Parkes, 1889)

Parkes also cites defence as a key reason for Federation. By the late nineteenth century, the dream of a peaceful world and the brotherhood of man, exemplified by the Great Exhibition of 1851 and the various colonial exhibitions of the 1870s and 1880s, was looking more and more illusory. Here is George Reid (1879, p. 7) in his entry for the 1879 Sydney Exhibition poetry competition:

And thus another lesson to mankind is taught,

Of amity by such co-operation wrought;

For here the fiercest competition for the prize,

The rival ardour to the general good allies.

This harmony of force was early understood,

By that first 'mong princes-ALBERT THE GOOD;

Bright harbinger of the restored, primeval plan,

That seeks the freedom yet the brotherhood of man!

The free trade ideals that had inspired Reid's utopianism had largely evaporated by the early 1890s. The world had become a more dangerous place.

This is not to say that higher ideals had been banished from the colonial world. The creation of a federated Australia was a noble cause. It would bring into being a new nation, a nation that was both Australian and British. I wonder what the Irish Catholics among my ancestors thought of the anti-Catholic Parkes' depiction of them as British. The Federation movement, it should be pointed out, was largely a Protestant enterprise.

Federation was an aspect of the growing cooperation and coordination of the various parts of the British Empire, although it is sobering to appreciate that it occurred as Australian troops were involved in a war against a part of that Empire that wished to secede. There is a logic in imperial development, as can be seen quite clearly in the case of Rome, whereby what begins as fairly loose rule over time becomes increasingly tight. Of course, Australians willingly supported the Empire, even as they sought jealously to protect their interests within that Empire.

To a large extent, the majority of Australians accepted that Parkes was correct and that they were building an Australian nation that was fundamentally British in nature. It is not untrue to say that the men who drew up the Commonwealth Constitution had a love affair with the British Constitution and saw it as the pinnacle pf political perfection (Chavura \& Melleuish, 2015). This raised some interesting issues. How was it possible to replicate the British Constitution in the Australian context especially given the fact that there is no single formal document? 
At the same time, following British precedence, those drawing up the constitution were reluctant to specify too closely the shape of that constitution in written terms. They feared that a written constitution would be too rigid and not able to evolve. Despite this reluctance, they had to draw up a written constitution. The delegates did not like theory; as one would expect of a group largely composed of common law lawyers, they considered themselves to be practical men. Even someone who we tend to think of as a liberal radical, Alfred Deakin, often sounds like a good Burkean conservative on constitutional matters (Chavura \& Melleuish, 2015).

In many ways, this cast of mind was a positive thing; the constitutional drafters avoided highfalutin statements about the values that the constitution would embody. They did not insert a Bill of Rights; they were very suspicious when it came to putting anything to do with religion in the document (Ely, 1976). What we get instead largely are the sorts of implicit values of late-nineteenth colonial liberal lawyers and politicians who had been moulded by the practices of responsible government.

The whole point of the exercise was to create a federal constitution that was acceptable to all those colonies wishing to come together. They were practical men seeking a workable outcome. Their primary interest was getting the mechanics correct and ensuring that their goal of a federated Australia was achieved. The constitution was focused on creating a workable federal system; the workings of parliament are only discussed insofar as they are impacted by the new federal structure. They did not need to discuss responsible government; they knew how it worked.

This approach had a number of consequences. One is that many of the key clauses of the constitution became the subject of horsetrading among the representatives of the various colonies. There was a division between the large colonies and the small ones. The Billites were more concerned with achieving the glory of an implemented constitution than with writing a good constitution (see Gorman \& Melleuish, 2018).

This is not to say that some of the key players, such as Barton and Griffiths, were centralists. Their subsequent careers as High Court judges proves otherwise. There was no real expectation that they were bringing into being a powerful Commonwealth government that would overshadow the states. Rather, it can be argued that the process of constitution-making allowed for the creation of a government that contained the potential, provided for by the constitution, to become centralising and powerful.

What does this all mean?

I would like to give a few suggestions:

- The coming of Federation did nothing to slow down the centralising tendencies inherent in the system of responsible government that formed the real foundation of Australian politics. The state governments continued to develop as they had 
in the second half of the nineteenth century. Once the opportunity arose, as it did during the First World War, Australian governments were able to exploit the centralising elements within the constitution, such as the defence powers, to begin their own centralisation.

- What this means is that the political instincts of the Australian people, and of the political culture that they created, are centralist. They are not jealous protectors of their local liberties and defenders of their communities. How could they be, when local government only became a serious matter after Federation? Sovereignty never extended to local self-governing communities but was claimed by state, Commonwealth and Empire (the Commonwealth did not become a sovereign entity in 1901). Australians were predisposed to hand over the running of things to governments who took decisions on their behalf. They wanted governments to do things for them, just as Commonwealth governments expected Britain to do things for it, especially in defence matters.

There was the occasional obstacle to this process. The Australian people elected a Labor government in 1910 and that government failed in two referendums in 1911 and 1913 to increase Commonwealth powers. This became part of a pattern whereby Commonwealth governments found it almost impossible to use referendums to extend their powers. In this regard it is interesting that both the 1913 referendums and the subsequent 1919 referendums had 49 per cent of the vote and the support of three states. It was a closely run thing. ${ }^{3}$

Although the Australian people have been reluctant to change the constitution through formal mechanisms, they have not resisted the long-term move towards the accumulation of power by the Commonwealth Government. One of the key ways in which that has occurred has been through High Court interpretation of the constitution, which, from quite an early stage, favoured the increase of Commonwealth power. While both Barton and Griffith, key players in drawing up the constitution, favoured the states, the introduction of new High Court justices in 1910, who had played no role in the constitutional conventions, meant that constitutional interpretation moved towards common law principles and literal interpretation and, in the long term, this meant increased Commonwealth power (Sawer, 1956, p. 106).

This process was accelerated by the use of the defence powers, which were only temporary, during the First World War. Geoffrey Sawer argues:

Thus judicial doctrine in this period markedly favoured the expansion of Commonwealth power and in particular gave the defence power a scope which could, for practical purposes, turn the Constitution, at least during grave and largescale wars, from a federal to a unitary one. (Sawer, 1956, p. 106)

3 The figures for all these referendums can be found on Wikipedia. 
With the retirement of both Barton and Griffiths in 1920, the direction of the High Court was consolidated by the Engineers case. ${ }^{4}$ Of course, the use by the Commonwealth Government of the defence power once again during the Second World War allowed for an increase in Commonwealth power. Moreover, as Sir Robert Menzies argued, it habituated the Australian people to look to the Commonwealth Government as the relevant authority, even in matters that were state government responsibilities (Menzies, 1967, p. 68).

Financial power was gradually accrued by the Commonwealth. On all these matters, Sir Robert Menzies' Central Power in the Australian Commonwealth is still worth reading (Menzies, 1967, pp. 74-92). Slowly, but surely, the capacity to raise taxation was largely vested in the Commonwealth Government. The states gave up their right to raise income tax during the Second World War. The High Court prohibited them from imposing a sales tax. The Australian federal system slipped into an increasingly worsening condition of vertical fiscal imbalance.

Following our argument regarding developments in the West in the late nineteenth and early twentieth centuries, one could argue that centralisation and the consolidation of Commonwealth power was an inevitable feature of twentiethcentury Australian political, social and economic development. The intriguing thing is that this process encountered so little resistance and was, leaving aside the failed referendums, widely embraced by both the political elite and the Australian people. The principal argument presented in this article is that one reason it happened so easily was that Australian political culture was moulded by the traditions of responsible government and the desire to follow the British Westminster system as much as possible. This is, and remains, a tradition that favours centralisation. Put another way: 'nation' has always trumped the federal compact.

It can be argued that some sort of union among the various Australian colonies would have occurred at some stage or other. Alternative history is not all that popular in Australia but in the 1940s G.V. Portus argued that even if David Syme had never owned The Age, protectionism would have triumphed in Australia (Portus, 1944, pp. 115-123). Taking a similar approach to Federation, what matters, under such an argument, is the timing of the federal union. The later that it occurred, the more centralist the constitution was likely to have been; the earlier, the looser the bonds tying together the various colonies would have been. Australia may have become a 'confederation' rather than a federation if the colonies had come together about the same time as Canada. It may have become a unitary state if the Labor Party was predominant.

4 Amalgamated Society of Engineers v Adelaide Steamship Co Ltd, (1920) 28 CLR 129; HCA 54 (31 August 1920). 
Having said all of this, it is worth reflecting that the centralist tradition in Australian politics has its real origins in the various colonial governments. They were centralist because that was the dominant feature of responsible government. An Australian continent dotted with quasi-independent entities would still be a continent home to polities founded on the principle of 'responsible government' administering centralised education and health systems. In this regard, and following on from John West, it may well have been the case that a principled federalism would have been able to infuse the politics of Australia with a much greater concern for limiting the power of governments. But that would have meant a belief in the principles of federalism among the wider population and much stronger local associations.

In the final analysis, the coming of Federation did little to prevent the long-term 'centralising' tendencies in Australian political life. The Commonwealth Government that came into being in 1901 was still fundamentally another version of responsible government. The real issue was, and remains, the sort of political culture that came into being in the 1850s and developed in the second half of the nineteenth century and formed the way in which those who drew up the Commonwealth Constitution, and became the political class of the new Commonwealth, thought and acted. It placed an imprint on Australian political practice that has remained with us until the present day.

\section{References}

Althusius, J. (1995). Politica (F.S. Carney, Trans.). Liberty Fund.

Belich, J. (2009). Replenishing the Earth: The settler revolution and the rise of the Angloworld, 1783-1939. Oxford University Press.

Chavura S. \& Melleuish, G. (2015). Conservative instinct in Australian political thought: The Federation debates, 1890-1898. Australian Journal of Political Science, 50(3), 512528. doi.org/10.1080/10361146.2015.1066308.

de Benoist, A. (2018). Democracy and populism: The Telos essays. Telos Publishing.

Docker, J. (1990). The nervous nineties. Oxford University Press.

Ely, R. (1976). Unto God and Caesar. Melbourne University Press.

Fernandes, C. (2018). Island off the coast of Asia. Monash University Press.

Gollan, R. (1960). Radical and working class politics: A study of eastern Australia. Melbourne University Press.

Gorman, Z. \& Melleuish, G. (2018). The nexus clause: A peculiarly Australian obstacle. Cogent Arts \& Humanities, 5(1), 1517591. doi.org/10.1080/23311983.2018.1517591. 
Hirst, J. (1988). The strange birth of colonial democracy. Allen \& Unwin.

Hobbes, T. (1991). Leviathan. Cambridge University Press.

Jaume, L. (2013). Tocqueville: The aristocratic sources of liberty (A. Goldhammer, Trans.). Princeton University Press. doi.org/10.23943/princeton/9780691152042.001.0001.

Kern, S. (2003). The culture of time and space 1880-1914. Harvard University Press.

Lang, J.D. (1840). Religion and education in America. Thomas Ward.

Melleuish, G. (1994). Utopians and sceptics: Competing images of democracy in Australia. In G. Stokes (Ed.), Australian political ideas (pp. 114-133). UNSW Press.

Melleuish, G. (1999). Distributivism: The Australian political ideal? Journal of Australian Studies, 23(62), 22-29. doi.org/10.1080/14443059909387496.

Melleuish, G. (2007). Colonial government. In B. Galligan \& W. Roberts (Eds), Oxford companion to Australian politics (pp. 112-114). Oxford University Press.

Melleuish, G. (2014). Despotic state or free individual? Two traditions of democracy in Australia. Australian Scholarly Publishing.

Menzies, R. (1967). Central power in the Australian Commonwealth. Cassell.

Nadel, G. (1957). Australia’s colonial culture. Cheshire.

Parkes, H. (1889). The Tenterfield oration. Foundation 1901. foundation1901.org.au/thetenterfield-oration/.

Pearson, C.H. (1893). National life and character. MacMillan.

Piggin, S. \& Linder, R.D. (2018). The fountain of prosperity: Evangelical Christians in Australian history 1740-1914. Monash University Press.

Portus, G.V. (1944). They wanted to rule the world: Studies of six dictators and other essays. Angus \& Robertson.

Reid, G.H. (1879). Lines addressed to New South Wales on the opening of the first Australian exhibition. Gibbs \& Shallard.

Roe, M. (1985). Nine Australian progressives: Vitalism in bourgeois social thought 1890. University of Queensland Press.

Sawer, G. (1956). Australian federal politics and law 1901-1929. Melbourne University Press.

Ward, J. (1976). Colonial self-government: The British experience. Macmillan.

Ward, J.M. (2001). The state and the people: Australian Federation and nation building 18701901. Federation Press.

West, J. (2001). Union among the colonies (G. Melleuish, Ed.). Australian Scholarly Publishing. 
This text is taken from Agenda, Volume 27 - Number 1, 2020, edited by William Coleman, published 2020 by ANU Press, The Australian National University, Canberra, Australia.

doi.org/10.22459/AG.27.01.2020.07 